\author{
E. Bergmeier, M. Ristow, J. Krause, S. Meyer \& M. Panitsa
}

\title{
Phytodiversity of Limnos (North Aegean, Greece)—an update and evaluation
}

\begin{abstract}
Bergmeier, E., Ristow, M., Krause, J., Meyer, S. \& Panitsa, M.: Phytodiversity of Limnos (North Aegean, Greece) — an update and evaluation. — F1. Medit. 31: 233-246. 2021. — ISSN: 1120-4052 printed, 2240-4538 online.

The present update to the flora of the island of Limnos in the North Aegean, based on our field studies in 2016 and 2018-2021, raises the currently known number of vascular plant species to 960 native taxa, 63 established neophytes and 27 species of as yet casual status, a total of 1,050 taxa. To substantiate these figures, we provide a catalogue of about 740 annotated records of 264 plant taxa, of which 231 taxa were not previously known to occur in the island. Sixty-eight taxa were found as new to the flora of the North Aegean biogeographic region. Among the biogeographically most significant of the newly recorded native species are Campanula lavrensis, Lactuca aculeata, Leontodon longirostris, Secale strictum subsp. anatolicum and Trifolium pachycalyx. The new finds strengthen the biogeographic affinities of Limnos with the Aegean islands further south. Most of the records were from agricultural landscapes and small-scale habitats. Several richness focus areas of newly recorded plants were identified. As a conclusion, the alleged species poverty of Limnos cannot be confirmed.
\end{abstract}

Key words: Floristic status, island flora, Mediterranean flora, neophytes, plant geography, plant records, species richness.

\section{Introduction}

With its landscapes of flats and gentle slopes the island of Limnos (Lemnos, $\left.\Lambda \eta \nu^{\prime} \varsigma_{\zeta}\right)$ in the centre of the North Aegean is unusual among the Aegean islands in terms of topography and geology as well as economically in its primacy of the agricultural sector. Favoured by the island's geomorphological and geological conditions, livestock and arable farming have a millennia-old tradition (Rauh 1949; Philippson 1959). With a population of about 16,000 inhabitants and a total area of $476 \mathrm{~km}^{2}$ it is the ninth largest island of Greece and the seventh largest Aegean island (but with about $257 \mathrm{~km}$ coastline length it ranks as number four in the Aegean) (ELSTAT 2011). The nearest mainlands are the Athos peninsula (Chalkidiki) to the west-northwest $59 \mathrm{~km}$ away and the Dardanelles region in northwestern Turkey $61 \mathrm{~km}$ to the east. Its distances from the neighbouring islands are $75 \mathrm{~km}$ northwest to Thasos, $43 \mathrm{~km}$ north to 
Samothraki, $22 \mathrm{~km}$ northeast to the Turkish island of Gökçeada (Imbros), $71 \mathrm{~km}$ southeast to Lesvos and $30 \mathrm{~km}$ south to Agios Evstratios. Limnos is amongst the earliest inhabited Aegean islands and already in the Early Bronze Age, around 3,000 BC, became an important place in the trade network (Kouka 2002).

The topography of Limnos is mostly gentle with extensive flatlands and low hills. The highest elevation, Vigla, is only $430 \mathrm{~m}$ above sea level and about two thirds of the island is lower than $100 \mathrm{~m}$. A considerable part of the flatlands is covered by alluvial deposits, generating mostly sandy, loamy or gravelly soils. Arable fields prevail, grown chiefly with barley, wheat and triticale, less common are oats, legumes such as cowpea, maize, sorghum and sesame. Coastal dunes and temporary coastal lakes (Chortarolimni, Aliki) form unique landscapes which are of eminent importance in the East Mediterranean for wildlife, especially migratory birds. Much of the eastern lowlands are wetlands, saltmarshes, brackish marshes or wet-dry grasslands used as cattle or sheep pastures; they are ground-water influenced or temporarily flooded. Most of the hilly terrain is covered by silty or sandy soils derived from sedimentary rock (mostly Eocene to Oligocene molasse of sandstone, conglomerates and marl) and to about one third from Early Miocene volcanic rocks (mostly andesites) and tuffs (IGME 1993; Higgins \& Higgins 1996). Most of the hillsides are, or have been, used mainly as sheep pasture. They carry phrygana (Aegean dwarf-shrub vegetation) and short grasslands. As a result of frequent irregular disturbance by tilling and fire the phrygana is dominated mostly by Sarcopoterium spinosum. Viticulture and cereal fields are locally common. Tall woody vegetation is fairly scarce on Limnos. Most remarkable are scattered trees and open woodlands of valonia oak (Quercus ithaburensis subsp. macrolepis), dense maquis of kermes oak (Quercus coccifera), riparian forests of Ulmus minor and Salix alba, brackish ground-water dependent open woods of Elaeagnus angustifolia and, in sites seasonally flooded by saline waters, Tamarix stands.

With the inventory by Panitsa \& al. (2003) the flora of Limnos was considered wellstudied. They surveyed in 1989 and 1996-97 a total of 79 sites all over the island and off-shore islets, focusing on semi-natural habitats. Moreover, the authors compiled many $20^{\text {th }}$ century records scattered in literature from the times of Rechinger $(1929,1943)$ and Rauh (1949) through to Economidou (1981), Browicz (1991a), Yannitsaros \& al. (2000), Biel (2000, 2002) and Tan \& al. (2002). However, a number of notable floristic additions published subsequently showed that the flora was by no means exhaustively explored (e.g., Tan \& al. 2008a, 2008b; Biel \& Tan 2011, 2014a, 2015; Baliousis 2014). All these floristic works were considered by Strid (2016) in his Atlas of the Aegean Flora. He critically evaluated the data assembled in the Hellenic floristic database (FHD) which, since the first collections by Butcher cited by Turrill (1922), cover a century of botanical research on the island.

The present study is the result of botanical field studies carried out independently by two teams - J. Krause and M. Ristow in 2016 and 2018-2019, and E. Bergmeier, S. Meyer and M. Panitsa in 2016 and 2018-2021. The fieldwork by the latter team was focused initially on the species composition of selected fields and farmsteads (mandras) in the frame of the Terra Lemnia project (https://terra-lemnia.net/en/) to promote sustainable traditional agropastoral practices of Limnos. Despite the local scope, it soon turned out that a considerable number of species found was not known to occur 
in the island, including floristic additions of importance from biogeographic, cultural and ecological perspectives. It further turned out that many species were observed by both teams, while others were found by one team only, thus complementing individual expertise, seasonal and geographical coverage. Realizing the teams' respective attempts and progress we decided to join forces, aiming at updating the previous floristic milestones by Panitsa \& al. (2003) and Strid (2016). The re-inventorying of the island flora is intended to not only update the plant richness numbers but also to improve the knowledge of the local flora in quantitative (plant population size, rarity) and qualitative terms (habitat affinities). We further ask whether there are focus areas of the new plant records and reconfirmations and where these floristic clusters are, to which habitats and landscapes the new findings belong, and which biogeographical conclusions can be drawn.

\section{Matherials and methods}

The present study is based on fieldwork carried out by the authors in 2016 and 20182021 covering spring (April, May) and autumn (end of September and October) seasons (Table 1). Our investigations were carried out in a total of 124 units of the arcminute grid (each unit has an area of about $263.5 \mathrm{ha}$ ), representing more than $70 \%$ of the total number of units (arcminute units counted if terrestrial to more than $50 \%$ ). We did not attempt to perform a spatially comprehensive floristic mapping. In the present paper, we provide new floristic records for the island (or a wider area) and reconfirmations of species reported by Rechinger (1943) and Rauh (1949) after more than 70 years. We also highlight corrections of former erroneous reports and specify omissions. Specifically, the criteria of taxa found by us and treated in this paper are:

- Taxa previously not known to occur in Limnos (or the North Aegean or wider geographical area);

- Mapped in Limnos by Strid (2016) based on unpublished data;

- Reported in literature but apparently incorrect taxonomic identity;

- Reported in literature but omitted by Strid (2016);

- Reported in literature only at higher taxonomic level (species or species group);

- Apparently not found in Limnos since more than 70 years.

We also provide a list of taxa reported in previous works but not found by us. Such a list appears useful as it includes species that are extinct, rare, or possibly erroneous, hence should be regarded with particular attention in future studies.

The taxa in the catalogue of new records and confirmations are listed in alphabetical order of families, and therein genera and species again in alphabetical order. The family assignation and taxonomy follows Euro+Med (2006+), the taxonomy of species and subspecies mainly Dimopoulos \& al. (2013) and Euro+Med (2006+). The annotations include taxon name, locality, elevation above sea level, coordinates (GPS data of WGS 84), habitat, date, observers or collectors with collection number. Voucher specimens are currently deposited in the cited authors' private herbaria. 
Table 1. Fieldwork: seasons, duration and numbers of new vascular plant records and confirmations for the present update. Researchers: B, Bergmeier; K, Krause; M, Meyer; P, Panitsa; R, Ristow.

\begin{tabular}{lllll}
\hline Year & Month & $\begin{array}{l}\text { Number of } \\
\text { days }\end{array}$ & Number of records & Researchers \\
\hline 2016 & Apr & 4 & 6 & M \\
& Oct & 13 & 85 & K, R \\
2018 & Apr & 8 & 125 & B, M, P \\
& May & 12 & 112 & K, R, M \\
2019 & Apr & 9 & 37 & B, M, P \\
& May & 15 & 105 & K, R, M \\
& Oct & 3 & 44 & B, M \\
2020 & Sep & 4 & 34 & B, M \\
2021 & Oct & 2 & 29 & B, M \\
& May & 13 & 169 & B, M \\
\hline
\end{tabular}

\section{Results and Discussion}

The present update of the flora of Limnos lists about 740 records of 264 vascular plant taxa noteworthy for floristic, taxonomic or biogeographic reasons. A total of 231 taxa were not previously known to occur in the island, and 68 were found new to the North Aegean biogeographic region (which consists mainly of the islands of Limnos, Thasos, Samothraki and $\mathrm{Aj}$. Evstratios). Several taxa were not currently known elsewhere in the Aegean (Bromus arvensis subsp. parviflorus, Leontodon longirostris, Secale strictum subsp. anatolicum and the established neophyte Opuntia microdasys), in Greece as a whole (Trifolium pachycalyx and the neophytes Chenopodium suecicum, Datura wrightii, Lathyrus cf. undulatus and Styphnolobium japonicum) or in Europe (Lactuca aculeata). Aegean endemics found as new in Limnos are Limonium sieberi and Saponaria jagelii, together with others confirmed by us, e.g. Anthemis werneri, Consolida arenaria, Polygonum icaricum and Silene grisebachii. In addition to the previously known local island endemic Erysimum rechingeri, we found a further three range-restricted species: Campanula lavrensis, an endemic of the Northwest Aegean, Lathyrus cf. undulatus, a showy endemic of Northwest Turkey which appears to be an established garden escape in Limnos, and Trifolium pachycalyx, described from Northwest Turkey but not reconfirmed there or anywhere else in the world since more than 80 years.

The complete floristic list is given in the Electronic Supplementary File 1 (ESF1).

\section{Confirmations and non-confirmations}

Our update includes confirmations of 16 species reported more than 70 years ago by botanists such as Rechinger $(1929,1943)$ and Rauh (1949). According to the compilation of published or otherwise communicated data in the FHD, these species have not been 
recorded since. Habitat continuity provided, there is remarkable perseverance in populations even of short-lived species. After almost a century, Galium verticillatum was found in the same site (the single known in the island) as Rechinger in 1927 (Rechinger 1929: 315). A population of wild pea, identified as Pisum elatius, was found in what appears to be the very same site (again the single one currently known in Limnos) as 50 years ago by the collector Jeavons whose specimen was documented under the name P. sativum.

The following taxa which were listed in the Limnos vascular plant inventory by Panitsa $\&$ al. (2003) but for various reasons not mapped for the island by Strid (2016) could also be confirmed by us: Allium scorodoprasum subsp. rotundum (L.) Stearn, Allium flavum L., Allium commutatum Guss., Hainardia cylindrica (Willd.) Greuter, Nigella arvensis subsp. glauca (Boiss.) A. Terracc., Phalaris paradoxa L., Prasium majus L. and Rhagadiolus edulis Gaertn.

We could not confirm the occurrence of 86 taxa reported in previous works and, except those marked with *, mapped for Limnos by Strid (2016). These taxa appear to be a heterogeneous group of (a) rare species overlooked by us, (b) species verifiable only in months that we did not cover such as between November and March, and (c) erroneous records, yet not clarified by obvious taxonomic, ecological or biogeographical reasons: Agrimonia eupatoria L., Allium rhodopeum Velen. (A. paniculatum subsp. villosulum (Halácsy) Stearn)*, A. sphaerocephalon var. aegaeum (Heldr. \& Halácsy) Hayek*, Anchusa azurea Mill. (A. italica Retz.), Arisarum vulgare O. Targ.Tozz., Armeria undulata Boiss., Arthrocaulon macrostachyum (Moric.) Piirainen \& G. Kadereit (Arthrocnemum macrostachyum (Moric.) K. Koch), Asclepias fruticosa L.*, Berteroa obliqua (Sm.) DC., Brachypodium pinnatum (L.) P. Beauv., B. retusum (Pers.) P. Beauv., Brassica napus L., Callitriche stagnalis Scop., Capparis orientalis Veill. (C. spinosa subsp. rupestris (Sm.) Nyman), Cerastium brachypetalum aggr.*, Cercis siliquastrum L., Consolida phrygia Soó, Crocus cartwrightianus Herb.*, C. olivieri J. Gay*, Crucianella latifolia L., Dactylis glomerata subsp. hackelii (Asch. \& Graebn.) Cif. \& Giacom., Dianthus pinifolius Tausch, Erodium botrys (Cav.) Bertol., E. laciniatum (Cav.) Willd., Eruca vesicaria (L.) Cav., Euphorbia apios L., E. pubescens Vahl, Filago cretensis Gand. subsp. cretensis, Goniolimon sartorii Boiss., Hedera helix L., Herniaria hirsuta subsp. cinerea (DC.) Cout., Hornungia petraea (L.) Rchb., Juncus subulatus Forssk., Lathyrus articulatus L., L. sphaericus Retz., Lemna minor L., Limonium ocymifolium (Poir.) Kuntze, Lomelosia divaricata (Jacq.) Greuter \& Burdet, Lupinus gussoneanus J. Agardh (L. micranthus Guss.), Luzula forsteri (Sm.) DC., Lythrum borysthenicum (Schrank) Litv., Malcolmia macrocalyx K. Rechinger, Malva nicaeensis All., M. pusilla Sm., Matthiola incana (L.) W.T. Aiton, Melilotus italicus (L.) Lam., M. segetalis (Brot.) Ser., Moenchia mantica (L.) Bartl., Muscari commutatum Guss., M. weissii Freyn., Ononis diffusa Ten., Onopordum Illyricum L., O. myriacanthum Boiss., Ophrys apifera Huds., O. umbilicata Desf., Origanum onites L., Orobanche amethystea Thuill., Parapholis marginata Runemark, Parietaria lusitanica L., Potamogeton nodosus Poir., Prunella laciniata (L.) L., Pterocephalus plumosus (L.) Coult., Ranunculus neapolitanus Ten., R. peltatus subsp. baudotii (Godr.) C.D.K. Cook, Romulea ramiflora Ten.*, Rosmarinus officinalis L., Rumex scutatus L.*, Ruppia cirrhosa (Petagna) Grande, Sambucus nigra L., Scandix grandiflora L. (S. australis subsp. grandiflora (L.) Thell.), Sideritis lanata L.*, Solanum dulcamara L., Spergula pentandra L., Spergularia media (L.) C. Presl (S. maritime (All.) Chiov.), Stachys germanica L., Stuckenia pectinata (L.) Börner (Potamogeton pectinatus L.), Tagetes minuta 
L., Tamarix hampeana Boiss. \& Heldr., Teucrium brevifolium Schreb., Trifolium grandiflorum Schreb., T. leucanthum M. Bieb., Tripolium pannonicum (Jacq.) Dobrocz. (Aster tripolium L.), Ulmus minor subsp. canescens Bartolucci \& Galasso, Urtica dioica L., Velezia rigida L., Vicia melanops Sm.

\section{Plant geographical conclusions}

The new records reinforce the biogeographic affinity of Limnos mainly with the south, i.e. linking it with other Aegean islands. Several native species among the newly recorded ones have their northernmost known populations in Limnos: Ambrosia maritima L., Arum concinnatum Schott, Atriplex davisii Aellen, Capparis sicula Veill., Convolvulus oleifolius Desr., Crataegus azarolus subsp. aronia (L.) Rouy \& E. G. Camus (Fig. 1), Echium arenarium Guss., Hordeum vulgare subsp. spontaneum (K. Koch) Thell., Limonium sieberi (Boiss.) Kuntze, Lolium subulatum Vis., Lotus subbiflorus Lag., Medicago bonarotiana Arcang., Medicago tuberculata (Retz.) Willd., Ononis serrata Forssk., Paronychia echinulata Chater, Phelipanche hedypnoidis Rätzel, Ristow \& Uhlich, Phragmites frutescens $\mathrm{H}$. Scholz, Potamogeton schweinfurthii A. Benn., Saponaria jagelii Phitos \& Greuter (Fig. 2), Secale strictum subsp. anatolicum (Boiss.) Hammer, Senecio leucanthemifolius Poir., and Vulpia ligustica (All.) Link. In contrast, only rather few have their southern-, southeasternor southwesternmost Aegean occurrences in Limnos (Bromus arvensis subsp. parviflorus (Desf.) H. Scholz, Campanula lavrensis (Tocl \& Rohlena) Phitos, Salicornia perennans Willd., Verbascum rupestre (Davidov) I.K. Ferguson (Fig. 3). Very few species have their westernmost (Heliotropium lasiocarpum Fisch. \& C.A. Mey., Lactuca aculeata Boiss. \& Kotschy, Ononis serrata Forssk., Trifolium pachycalyx Zohary) and only one of the newly recorded taxa (Aira caryophyllea L.) its easternmost known populations in the island.

\section{Floristic focus areas}

In Limnos, the most important arcminute grid units - in terms of floristic novelties - are the following: $39^{\circ} 54^{\prime} / 25^{\circ} 08^{\prime}$ (to the west of $\mathrm{Aj}$. Dimitrios), $39^{\circ} 51^{\prime} / 25^{\circ} 07^{\prime}$ (southwest of Kontias), $39^{\circ} 51^{\prime} / 25^{\circ} 10^{\prime}$ (Diapori), 39 $50^{\prime} / 25^{\circ} 10^{\prime}$ (isthmus and northernmost Fakos peninsula) and $39^{\circ} 52^{\prime} / 25^{\circ} 03^{\prime}$ (Myrina, town). Altogether, we identified the following as the richest floristic areas of the island (single or clustered grid units): (a) The topographically diverse volcanic rock area between Therma and Aj. Dimitrios; (b) the town of Myrina with coast and fortress hill; (c) the coastal flats southwest of Kontias; (d) the coastal flats and andesite domes just E of Kontias; (e) the coastline and coastal flats at both ends of the isthmus of Diapori with the northern part of the Fakos peninsula; (f) the seasonal lake of Chortarolimni with the sand flat called Agiogiannides and Keros beach in the far east of Limnos; (g) the area north and northeast of the lagoon of Aliki in the island's far east; (h) the area north of Plaka in the far northeast and (i) the coastal area of Aj. Sozon and the beach of Louri in the far southeast of Limnos.

\section{Focus habitats}

An evaluation of our plant records with sufficiently unambiguous habitat specification, a total of 721, revealed that more than one third of the records were made in arable landscapes (cultivated and fallow arable land, field margins and other dry ecotones) which indeed represent about one third of the island's area, and that coastal and other small-scale 


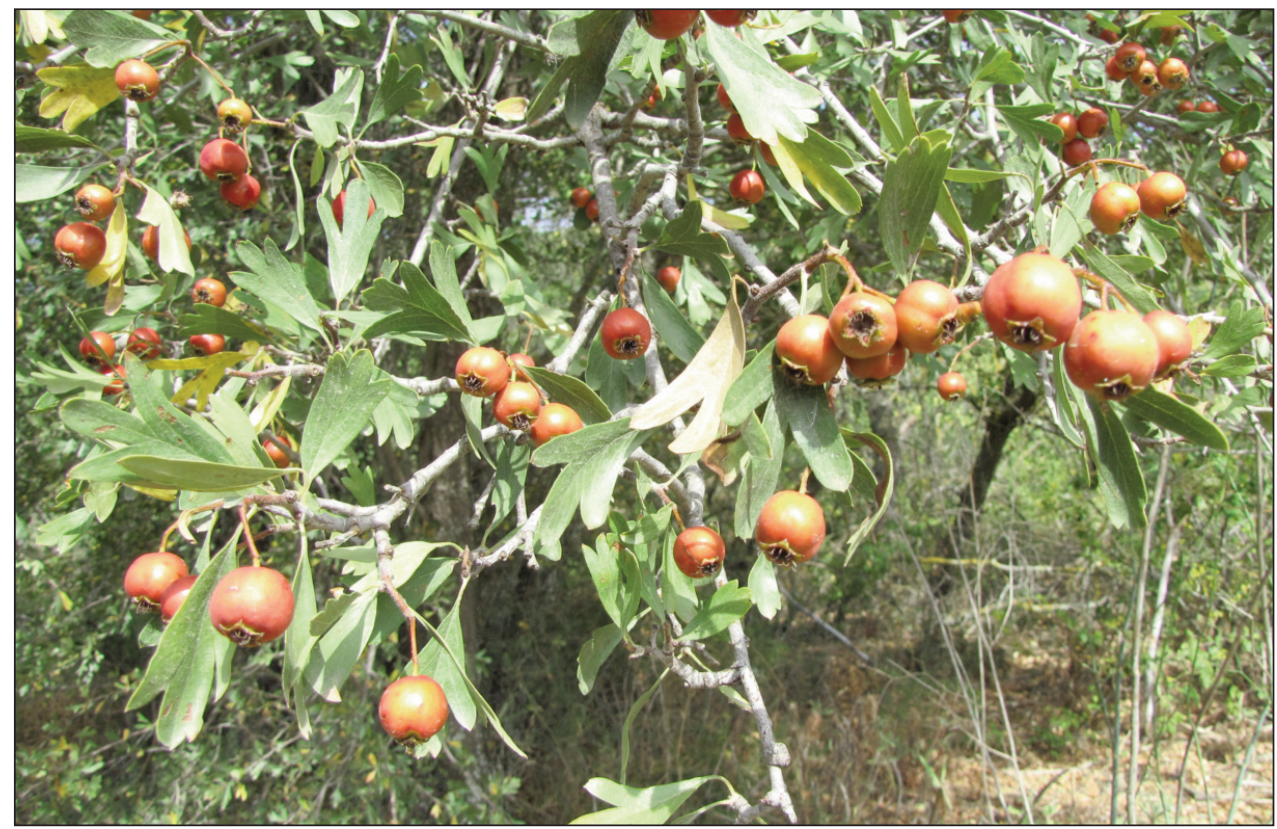

Fig. 1. Crataegus azarolus subsp. aronia, SW Aj. Dimitrios, 21 September 2021, photo E. Bergmeier.

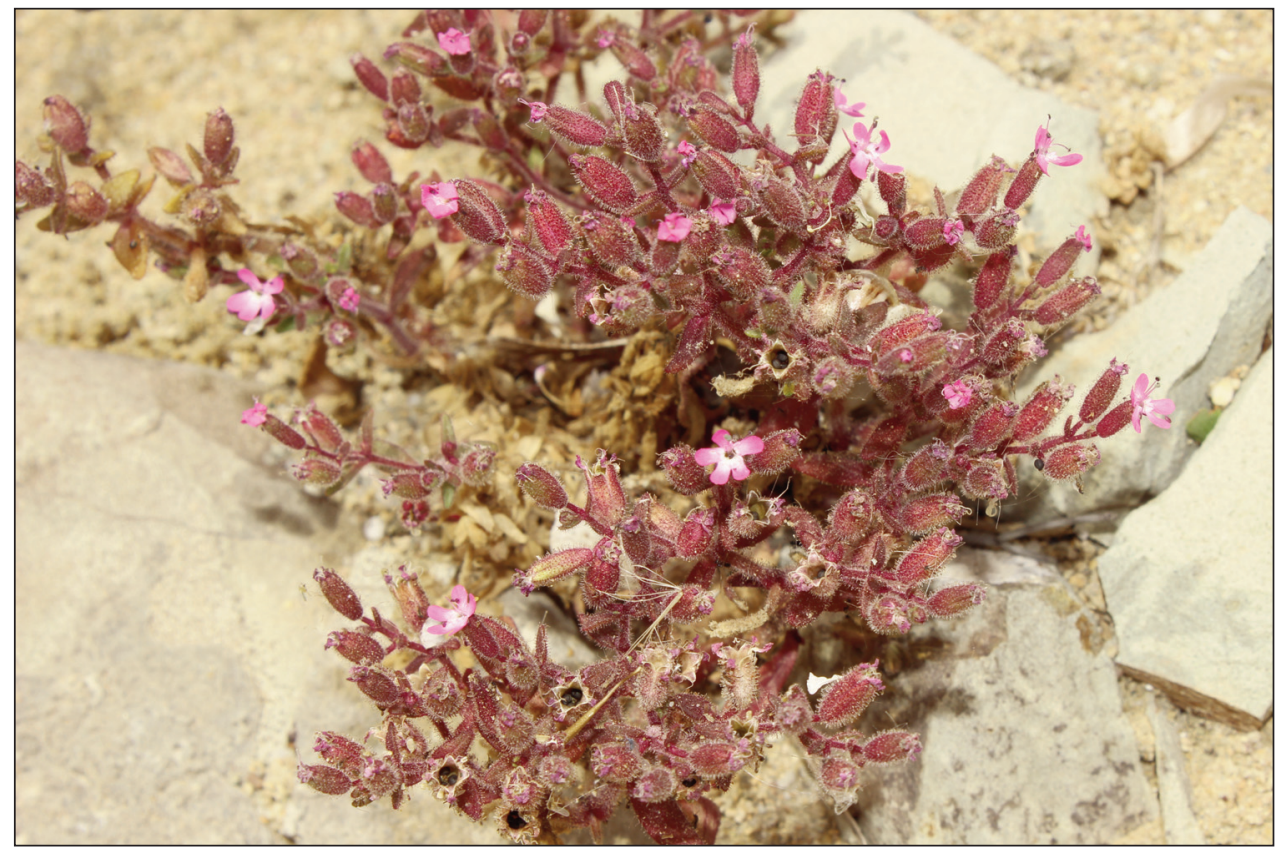

Fig. 2. Saponaria jagelii, Paralia Louri SW Aj. Sozon, 9 May 2018, photo J. Krause. 


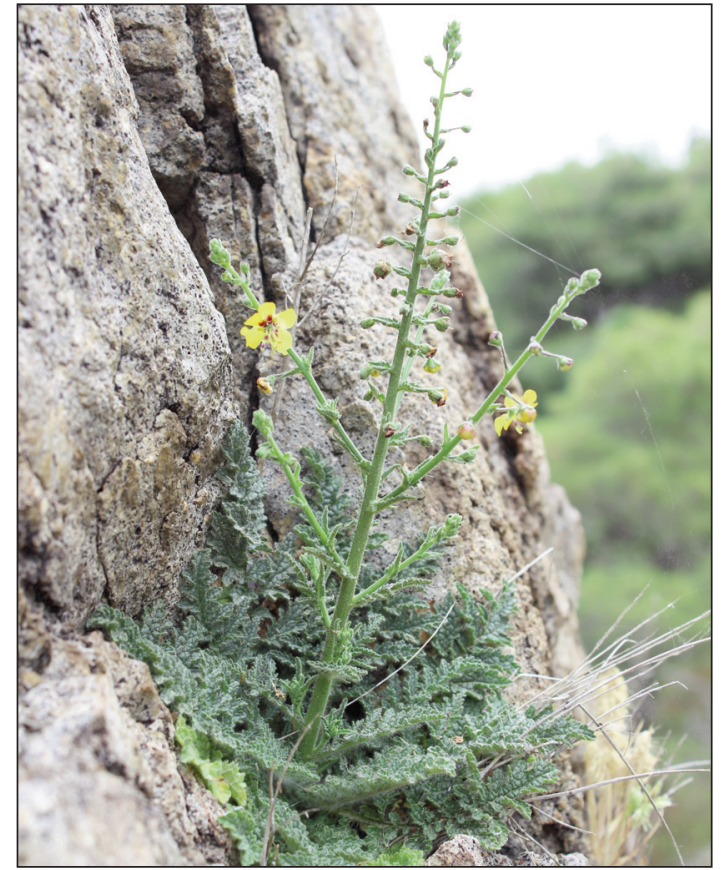

Fig. 3. Verbascum rupestre, northern edge of Kontias, 10 May 2018, photo J. Krause.

habitats (dunes, ruderal, semiwet grassland, saltmarsh, rocks and cliffs, aquatic and other wet habitats) are represented by almost $40 \%$ of our records (Table 2). Although most previously published plant records lack habitat specifications, it may be assumed that (a) the focus was then on large-scale seminatural habitats (such as phrygana and dry grasslands), and that (b) the habitats listed above as being well-represented among our records had remained understudied but are of considerable importance for the flora of Limnos.

Table 2. Habitat types represented by documented plant records.

\begin{tabular}{lr}
\hline Habitats & Number of records (\%) \\
\hline Arable land & 20.8 \\
Dry linear habitats & 14.3 \\
Phrygana & 14.0 \\
Coastal sands & 8.3 \\
Ruderal habitats & 7.8 \\
Dry herbaceous grassland & 6.5 \\
Semiwet grassland & 6.5 \\
Saltmarsh & 5.3 \\
Scrub and woods & 5.0 \\
Wet or semiwet linear habitats & 4.6 \\
Rocks and cliffs & 3.7 \\
Aquatic habitats and wetland & 3.2 \\
\hline
\end{tabular}




\section{Species richness}

The new records raise the currently known species richness of Limnos to a total of 1,050 vascular plant taxa growing spontaneously in the wild. This number comprises 1,035 species plus 15 additional subspecies (i.e. fifteen species are represented by two subspecies). By comparison, the island inventory by Panitsa \& al. (2003) listed 642 taxa growing in the wild, and Strid (2016) mapped 783 such taxa in Limnos. The difference between the two works is chiefly due to $21^{\text {st }}$ century records published after Panitsa \& al. (2003), namely by Tan \& al. (2008a, 2008b), Biel \& Tan (2011, 2014a, 2015) and Baliousis (2014), and to a minor extent due to differences of opinion in questions of naturalization and status assessment or for taxonomic reasons.

The figures given above for taxa "growing spontaneously in the wild" include native species (including those assumed archaeophytes), established neophytes and casual, i.e. non-established, neophytes. Species cultivated in gardens or fields for agricultural or ornamental purposes without significant spontaneous occurrences remained disregarded. They include a total of 43 species in literature (chiefly Thomas \& al. 2012). The above-mentioned figures are based on our census and differ slightly from those in the original works of Panitsa \& al. (2003) and Strid (2016) owing to differences in the assessment of the naturalization status of certain species. In our updated census we assess 960 taxa as native (including archaeophytes), 63 as established neophytes, and 27 as non-established casuals. Of course, doubts remain as to the correct status assessment of some species.

Panitsa \& al. (2003) attributed Limnos a "low floristic diversity" and an "unusually low [number of taxa] compared to other Greek islands with a comparable or even smaller size". Factors responsible for this, they assumed, are both genuine (low elevations, absence of limestone cliffs) and human-made (grazing, fires, camping). Certain habitats, otherwise more or less widely distributed and common in the North Aegean, such as calcareous cliffs, sea cliffs, thick sclerophyllous, coniferous and deciduous forests, rivulets and temporary streams, are indeed rare or absent in Limnos. It can also be expected that millennia-old human interference has much influenced the local flora and landscape over time. However, three facts can be ascertained: (1) The recent species pool of the habitats determining the overall appearance of the landscape of Limnos, such as arable land, land-use borderlines, phrygana, low-growing pastures, ruderal sites, saltmarshes, dunes and reed-beds, is by no means poor or impoverished compared to other island floras. (2) The difference in overall species richness between Limnos, with the unexpectedly large number of new records now better known than at the time of the first inventory twenty years ago, and other Aegean islands similar in size such as Samos (Christodoulakis 1986, Snogerup \& Snogerup 1993) and Chios (Snogerup \& al. 2001) is not as wide as it seemed. The remaining difference is easily explained by the much less marked topographic variation of Limnos and by the proximity of the two East Aegean islands to the (Anatolian) mainland. The fact that Samothraki, the northern neighbouring island and less than half the area extent of Limnos, equals the latter in floristic diversity (Biel \& Tan 2014b) is also explained by the much more pronounced vertical extension of Samothraki. (3) We did not find evidence of pronounced floristic turnover but of considerable resilience and permanence, especially in view of the reconfirmations of plant records after more than 70 years. Over $91 \%$ of the island's flora consists of native species most of which are expected to be long-time residents in Limnos (although it can- 
not be ruled out that some of the plants considered native in the Aegean or Greece were introduced to the island at some time). Only $2.6 \%$ appear to be recent casual introductions that may or may not become established in Limnos.

\section{Threats and conservation}

It is remarkable that the impression that Rauh (1949: 610) got of Limnos as a "GetreideInsel" (cereals island), is now, about 80 years later, still fully understandable. However, the proportion of cultivated land must have been considerably higher than it is today, mainly as a result of the 1950s-1970s Greek emigration waves which concerned among others especially islands such as Limnos (Afentoulis 2014). The decades since then have seen both ongoing abandonment of arable and pasture lands in the hilly and remote parts of the island as well as an intensification of agricultural practices including the use of synthetic fertilizers and pesticides. Both must have affected the populations of a number of now uncommon or rare wild arable (segetal) plants. While many segetal plants are still perhaps nearly as common in Limnos as they were in the days of Rauh (1949) who listed about 45 weeds of cereal crops and field margins, some species encountered by him have become scarcer (e.g., Agrostemma githago, Bifora testiculata, Leontice leontopetalum, Lolium temulentum, Medicago scutellata, Papaver hybridum, Ranunculus arvensis), and others, now restricted in Limnos to just one or few fields (Allium cyrilli, Bupleurum subovatum, Gladiolus italicus, Glaucium corniculatum, Medicago bonarotiana and Vaccaria pyramidata), were probably more widespread once. As far as we can see there appears to be no native species of natural environments in Limnos currently declining or in risk of extinction owing to traditional land-use, but some rare species of arable fields such as those mentioned above are threatened by intensification or neglect of the principles of traditional forms of smallholder farming (Bergmeier \& Meyer 2018).

While mass tourism is one of the major drivers of habitat and biodiversity loss in the Mediterranean it is only of minor and rather local importance in Limnos, at least in comparison to other Aegean islands. As many of the island's roughly 30 sandy beaches are extensive and some remote, sizable populations of typical dune plants are extant and in good condition such as those of the flagship species Pancratium maritimum as well as of other important coastal matrix plants such as Centaurea spinosa. Red-listed or threatened dune plants such as the rare Aegean endemics Consolida arenaria and Saponaria jagelii as well as Malcolmia nana are local in Limnos and potentially vulnerable due to inadvertent habitat destruction.

The construction of the island's airport north of the Moudros Gulf, arguably the most severe impact in the landscape of Limnos in the last century, brought about severe losses of semi-wet pastures, coastal grasslands and saltmarsh with their associated characteristic flora and wildlife. Fortunately, there are extensive semi-wet grasslands and saltmarshes extant locally in the south and especially in the east of the island where typical plants of such endangered habitats occur, including Trachomitum sarmatiense and Trifolium pachycalyx which have not been recorded anywhere else in Greece, and rarities of ecological significance found as new such as Leontodon longirostris, Trifolium squamosum and Vulpia ligustica. Large stretches of these sin-

\footnotetext{
* including those reported in the ESF1.
} 
gularly important habitats still occur in exceptional size and excellent quality in Limnos. The maintenance of large hydrologically intact areas unaffected by construction works is one of the most vital necessities in the field of nature and landscape conservation in the island. The designation of three Natura 2000 areas, as part of the European network of nature protection areas, is an important step. They cover at least some of the floristic focus areas worked out above such as the Fakos peninsula, Diapori, and the temporary lakes of Aliki and Chortarolimni. However, they are not strictly protected in terms of how they are used or not used by people, and management plans still await completion.

\section{Conclusion}

Even with the present update, the state of knowledge of the Limnian flora should not be understood as complete. We can, however, conclude that the previous perception of the island's low floristic diversity was premature, apparently as a result of recording deficit chiefly in the agricultural landscapes. The high number of new records corroborates that the species richness of Limnos does not lag behind from a biogeographic point of view. There are several eminent floristic locations in the island that rank among the first in the Aegean and which deserve every effort for their conservation. Outstanding focus areas with extraordinary habitat characteristics as discussed above, in particular saltmarsh, dune, diverse traditional arable land, semi-wet rangeland and some rock habitats require careful multidisciplinary monitoring to avoid administrative attention deficits and deterioration.

\section{Acknowledgements}

We have been supported by specimen identifications and confirmations and give our thanks to Gianniantonio Domina, Palermo (Portulaca), Matthias Erben, Munich (Limonium, Goniolimon), Stefan Rätzel, Frankfurt a. d. Oder (Ornithogalum), Filip Verloove, Meise (Opuntia), Gerhard Wiegleb, Cottbus (Ranunculus subgen. Batrachium, Potamogeton), and Rolf Wißkirchen, Remagen (Xanthium). Many thanks also to Arne Strid, Ørbæk, for providing us with an extract of the Flora Hellenica Database. EB, SM and MP appreciate the collaboration with the Terra Lemnia ("Lemnos island - A characteristic agro-pastoral mosaic of high biodiversity in the Aegean Sea", funded by MAVA, Fondation pour la Nature) project team as well as the financial support by MedINA to the travels.

\section{References*}

Afentoulis, M. 2014: North Aegean Greek islander migration to Australia-1950s to 1970s-'For a better life we came...'. Oral History Society Annual Conference (Community voices: Oral history on the ground). - Manchester.

Baliousis, E. 2014: Recent data from the flora of the island of Limnos (NE Aegean, Greece): New alien invasive species affecting the agricultural economy of the island. - Edinb. J. Bot. 71(2): 275-285.

Bergmeier, E. 2021a: Leontodon longirostris (Finch \& P. D. Sell) Talavera - Pp. 356-357 in: RaabStraube E. von \& Raus Th. (eds), Euro+Med-Checklist Notulae, 14. - Willdenowia 51: 355368. https://doi.org/10.3372/wi.51.51304 
— 2021b: Datura wrightii Regel - Pp. 363 in: Raab-Straube E. von \& Raus Th. (eds), Euro+MedChecklist Notulae, 14. - Willdenowia 51: 355-368. https://doi.org/10.3372/wi.51.51304

—, Krause, J. \& Ristow, M. 2021: Trifolium pachycalyx Zohary - Pp. 361-363 in: Raab-Straube E. von \& Raus Th. (eds), Euro+Med-Checklist Notulae, 14. - Willdenowia 51: 355-368. https://doi.org/10.3372/wi.51.51304

— \& Meyer, S. 2018: Segetal plants of winter-annual crop fields in the Aegean islands - viewed in the contexts of landscape and traditional agricultural practice. - Ber. Reinhold-Tüxen-Ges. 30: 73-84.

— \& - 2021: Lactuca aculeata (Asteraceae), a crop wild relative new to Europe. - Fl. Medit. 31: 53-58. https://doi.org/10.7320/FlMedit31.053

—, Sakellarakis, F.-N., Strid, A. \& Swinkels, C. 2020. New additions to the flora of Prespa, Greece. - Phytol. Balcan. 26(1): 103-130.

Biel, B. 2000: Zur Orchideenflora der Insel Limnos. - Ber. Arbeitskreises Heimischer Orchid. 17(2): 51-78.

- 2002: Contributions to the flora of the Aegean islands of Lesvos and Limnos, Greece. Willdenowia 32: 209-219.

— \& Tan, K. 2011: Reports 1-19. - Pp. 248-250 in: Vladimirov, V. \& Tan, K. (eds): New floristic records in the Balkans: 16. - Phytol. Balcan. 17(2): 247-264.

— \& - 2014a: Reports 13-61. - Pp. 269-273 in: Vladimirov, V., Dane, F., Matevski, V. \& Tan, K. (eds): New floristic records in the Balkans: 25. - Phytol. Balcan. 20(2-3): 267-310.

— \& - 2014b: Flora of Samothraki. - Athens.

— \& - 2015: Reports 70-187. Pp. 62-72 in: Vladimirov, V., Dane, F. \& Tan, K. (eds): New floristic records in the Balkans: 26. - Phytol. Balcan. 21(1): 53-91.

Böhling, N. \& Scholz, H. 2003: The Gramineae (Poaceae) of the Southern Aegean islands (Greece): Checklist, new records, internal distribution. - Ber. Inst. Landschafts- Pflanzenökol. Univ. Hohenheim, Beih. 16. - Stuttgart.

Bothmer, R. von, Strid, A., Biel, B. \& Tan, K. 2014: Report 113. - Pp. 279-280 in: Vladimirov, V., Dane, F., Matevski, V. \& Tan, K. (eds): New floristic records in the Balkans: 25. - Phytol. Balcan. 20(2-3): 267-310.

Boyce, P. 1993: The genus Arum. - London.

Browicz, K. 1991a: Trees and shrubs of Lemnos Is. (Greece). - Arbor. Kórnickie 36: 5-25.

- 1991b: Crataegus $\times$ ruscinonensis var. aronioides (Rosaceae), a new nothospecies and nothovariety for the flora of Greece. - Willdenowia 21: 113-117.

Christensen, K. I. 1992: Revision of Crataegus sect. Crataegus and nothosect. Crataeguineae (Rosaceae-Maloideae) in the Old World. - Syst. Bot. Monogr. 35: 1-199.

Christodoulakis, D. 1986: Die Flora und Vegetation der Insel Samos (Griechenland). - Patras [in Greek with German summary].

Del Carratore, F., Garbari, F. \& Jarvis, C. 1998: The application of the Linnaean names Salvia pratensis, S. agrestis, S. haematodes, S. verbenaca and S. clandestina (Lamiaceae). - Pl. Biosyst. 132: 169-176.

Dimopoulos, P., Raus, T., Bergmeier, E., Constantinidis, T., Iatrou, G., Kokkini, S., Strid, A. \& Tzanoudakis, D. 2013: Vascular plants of Greece: an annotated checklist. - Englera 31: 1-372.

Economidou, E. 1981: Le milieu terrestre de l'île de Limnos et ses reliques de forêts. - Biol. Écol. Médit. 8(3-4): 129-138.

ELSTAT (Ellinikí Statistikí Archí) 2011: Statistical Yearbook of Greece 2009 \& 2010. - Pireas [in Greek].

Euro+Med 2006+: Euro+Med Plantbase — the information resource for Euro-Mediterranean plant diversity. - https://www.emplantbase.org/home.html [Last accessed 27/8/2021].

Evthimiadis, P., Zamanis, A. \& Skorda, E. 1985: The two-rowed wild barley from four islands of Greece. - Sveriges Utsädesfören. Tidskr. 95: 63-70. 
Flora Ionica Working Group 2016+: Flora Ionica - An inventory of ferns and flowering plants of the Ionian Islands (Greece). - Published at https://floraionica.univie.ac.at [Last accessed 26 Jun 2021].

Garve, E. 2016: Atriplex Linnaeus 1753. - Pp. 361-363 in: Kleinsteuber, A., Ristow, M. \& Hassler, M. (eds), Flora von Rhodos und Chalki, 1. - Karlsruhe.

Greuter, W. 2003: The Euro+Med treatment of Cichorieae (Compositae) - generic concepts and required new names. - Willdenowia 33: 229-238.

Güemes J. \& Molero J. 2006: 5. Fumana (Dunal) Spach. - Pp. $422-436$ in: Castroviejo, S., Aedo, C., Cirujano, S., Laínz, M., Montserrat, P., Morales, R., Muñoz Garmendia, F., Navarro, C., Paiva J. \& Soriano C. (eds) Flora Iberica, 3 (2nd ed.). - Madrid.

Hanelt, P. 1963: Monographische Übersicht der Gattung Carthamus L. (Compositae). Feddes Repert. 67: 41-180.

Hedge, I. C. 1970: Onobrychis Adans. - Pp. 560-589 in: Davis, P. H. (ed.), Flora of Turkey and the East Aegean Islands, 3. - Edinburgh.

Hempel, W. 2012: Revision und Phylogenie der Arten der Gattung Melica L. (Poaceae) in Eurasien und Nordafrika. - Feddes Repert. 122: 1-253.

Higgins, M. D. \& Higgins, R. 1996: A geological companion to Greece and the Aegean. - London.

Hügin, G. 1998: Die Gattung Chamaesyce in Europa. Bestimmungsschlüssel mit taxonomischnomenklatorischen Anmerkungen. - Feddes Repert. 109: 189-223.

IGME (Institute of Geology and Mineral Exploration) 1993: Geological Map of Greece 1:50,000. Limnos Island. - Athens.

Koopman, J. \& Więcław, H. 2017: The section Phaestoglochin (Carex, Cyperaceae) in the Netherlands. - Gorteria 39: 79-87.

Kouka, Ou. 2002: Siedlungsorganisation in der Nord- und Ostägäis während der Frühbronzezeit (3. Jt. v.Chr.). Teil I, Text. (Internationale Archäologie 58) - Rahden/Westf.

Mosyakin, S. L. 2017: Taxonomic and nomenclatural notes on Pontic-Mediterranean coastal and some Australasian taxa of Salsola (Chenopodiaceae). - Ukr. Bot. J. 74: 521-531.

Panitsa, M., Snogerup, B, Snogerup, S. \& Tzanoudakis, D. 2003: Floristic investigation of Lemnos island (NE Aegean area, Greece). - Willdenowia 33: 79-105.

Philippson, A. 1959: Das Aegaeische Meer und seine Inseln. In: E. Kirsten (ed.), Die griechischen Landschaften. Eine Landeskunde von Alfred Philippson, 4. - Frankfurt, Main.

Rauh, W. 1949: Klimatologie und Vegetationsverhältnisse der Athos-Halbinsel und der ostägäischen Inseln Lemnos, Evstratios, Mytiline und Chios. - Sitzungsber. Heidelberger Akad. Wiss., Math.-Naturwiss. K1. [1949](12): 511-615.

Raus, T. \& Kleinsteuber, A. 2016: Cistaceae. - Pp. 373-379 in: Kleinsteuber, A., Ristow \& Hassler, M. (eds): Flora von Rhodos und Chalki, 1. - Karlsruhe.

Rechinger, K. H. 1929: Beitrag zur Kenntnis der Flora der ägäischen Inseln und Ost-Griechenlands. - Ann. Naturhist. Mus. Wien 43: 269-340 (+ 2 plates).

- 1949: Flora Aegaea. Flora der Inseln und Halbinseln des ägäischen Meeres. - Akad. Wiss. Wien, Math.-Naturwiss. K1., Denkschr. 105(1): i-xx $+1-924+25$ plates +3 maps.

Richards A. J., Biel B., Štěpánek J. \& Kirschner J. 2015: Taraxacum limnoticum (Asteraceae) from the Aegean, Greece. - Phytol. Balcan. 21: 149-154.

Rilke, S. (1999): Revision der Sektion Salsola s.l. der Gattung Salsola (Chenopodiaceae). - Bibl. Bot. 149: 1-189.

Ristow, M. 2016: Chenopodium Linnaeus 1753. - Pp. 366-369 in: Kleinsteuber A., Ristow M. \& Hassler M. (eds), Flora von Rhodos und Chalki, 1. - Karlsruhe.

—, Krause, J. \& Bergmeier E. 2021: Saccharum spontaneum L. - Pp. 360-361 in: Raab-Straube E. von \& Raus Th. (eds), Euro+Med-Checklist Notulae, 14. - Willdenowia 51: 355-368. https://doi.org/10.3372/wi.51.51304 
Salas Pascual, M. \& Verloove, F. 2019: Opuntia microdasys (Lehm.) Pfeiff. - P. 424 in: RaabStraube E. von \& Raus T. (ed.), Euro+Med-Checklist Notulae, 11 [Notulae ad floram euromediterraneam pertinentes No. 40]. - Willdenowia 49: 421-445.

Scoppola, A. 2019: An annotated key to the species of Gastridium (Poaceae) with distributional novelties to the Italian territory. - Atti Soc. It. Sci. Nat. Museo Civ. Stor. Nat. Milano 6(2): 29-36.

Snogerup, S. \& Snogerup, B. 1993: Additions to the flora of Samos, Greece. - Fl. Medit. 3: 211-222.

—, - Phitos, D. \& Kamari, G. 2001: The flora of Chios island (Greece). - Bot. Chron. (Patras) 14: 5-197.

Strid A. 2016: Atlas of the Aegean flora. Part 1: Text \& Plates. Part 2: Maps - Englera 33(1): 1-700, 33(2): $1-878$.

Tan, K., Sfikas, G. \& Vold, G. 2002: Consolida arenaria Carlström. - P. 203 in: Greuter, W. \& Raus, T. (eds): Med-Checklist Notulae, 21. - Willdenowia 32: 195-208.

—, — \& — 2008a: Reports 99-104. - Pp. 146-147 in: Vladimirov, V., Dane, F. \& Tan, K. (eds): New floristic records in the Balkans: 7. - Phytol. Balcan. 14(1): 131-148.

—, — \& - 2008b: Reports 76-82. - Pp. 445-446 in: Vladimirov, V., Dane, F. \& Tan, K. (eds): New floristic records in the Balkans: 9. - Phytol. Balcan. 14(3): 429-451.

Telesca, L., Belluscio A., Criscoli A., Ardizzone G., Apostolaki E. T., Simonetta Fraschetti, S., Gristina M., Knittweis L., Martin, C. S., Pergent, G., Alagna A., Fabio Badalamenti F., Garofalo G., Gerakaris V., Pace, M. L., Pergent-Martini C. \& Salomidi, M. 2015: Seagrass meadows (Posidonia oceanica) distribution and trajectories of change. - Sci. Rep. 5: 12505 https://doi.org/10.1038/srep12505.

Thomas, K., Thanopoulos, R., Knüpffer, H. \& Bebeli, P. J. 2012: Plant genetic resources of Lemnos (Greece), an isolated island in the Northern Aegean Sea, with emphasis on landraces. - Genet. Resour. Crop Evol. 59: 1417-1440.

Turrill, W. B. 1922: A contribution to the flora of the Nearer East. - Bull. Misc. Inform. [1922](9): 291-298.

Yannitsaros, A., Economidou, E., Delipetrou, P., Bazos, I. \& Georghiou, K. 2000: New data on the distribution of some plant taxa in the Aegean area. - Pp. 118-121 in: Proceedings of the 8th Scientific Congress of the Greek Botanical Society. - Patras.

Addresses of the authors:

Erwin Bergmeier ${ }^{1 *}$, Michael Ristow ${ }^{2}$, Josephin Krause $^{3}$, Stefan Meyer $^{1}$ \& Maria Panitsa $^{4}$,

${ }^{1}$ University of Göttingen, Vegetation and Plant Diversity Analysis, Untere Karspüle 2, 37073 Göttingen, Germany; erwin.bergmeier@bio.uni-goettingen.de; smeyer1@gwdg.de

${ }^{2}$ University of Potsdam, Plant Ecology and Nature Conservation, Am Mühlenberg 3, 14476 Potsdam, Germany; ristow@uni-potsdam.de

${ }^{3}$ Jonasstr. 48, 12053 Berlin, Germany; josi.krause@mail.de

${ }^{4}$ University of Patras, Department of Biology, Division of Plant Biology, Panepistimiopolis, 26504 Rio, Greece; mpanitsa@upatras.gr

* Corresponding author 